\title{
Leaf Boundary-Layer Vapor Transfer Coefficient in Light Winds Affected by Buoyancy
}

\author{
Tetsuya Haseba, Kenji Aibara* ${ }^{*}$ Koji Moriya**, \\ Atsushi Nishikawa and Daijiro Ito

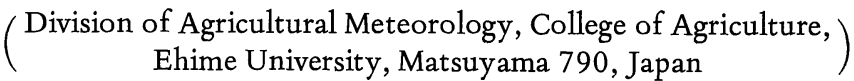

Air flow generated by thermal convection was used in a low-speed wind tunnel to evaluate leaf boundary-layer transfer coefficients. The $20 \mathrm{~cm}$ long test section had a $25 \mathrm{~cm} \times 25 \mathrm{~cm}$ square cross-section over which a stable laminar air flow with turbulence intensities of less than 0.02 was produced under a range of flow speed from 10 to $130 \mathrm{~cm} \cdot \mathrm{sec}^{-1}$.

By applying this wind tunnel, water-vapor transfer coefficients were evaluated for heated leaf models with various temperature differences between the model surface and the air. Transfer coefficients were also evaluated for non-heated leaf models of various lengths and widths both between 1 and $16 \mathrm{~cm}$. From the experimental results, the effect of buoyancy on the coefficient was investigated.

Transfer coefficients obtained from the present experiments were larger than the theoretical laminar forced-convection ones. The ratio of the transfer coefficients to the theoretical forcedconvection ones was represented as a function of the aspect ratio, the Grashof and Reynolds numbers.

It is concluded that, in light winds, the free-convection over the leaf surface and the advection around the edge produce a larger boundary-layer transfer than the pure forced-convection one.

Key words: Boundary layer, Light Wind, Low speed wind tunnel, Plant leaf, Vapor transfer coefficient.

キーワード：境界層, 水蒸気輸送係数, 微速風洞, 微風, 模型葉

\section{Introduction}

Within a plant canopy and in a plastic film greenhouse, wind or air flow is usually light, and most plants are thus growing under conditions of slight air movement. In still air and light winds at speeds of less than $1 \mathrm{~m} \cdot \mathrm{sec}^{-1}$, the coefficient of mass transfer across the boundary-layer on a plant leaf is occasionally comparable to or smaller than the leaf conductance, which depends mainly upon stomatal aperture (Impens et al., 1967; Haseba and Takechi, 1972). Accordingly, the boundary-layer transfer coefficient is probably one of the limiting factors of transpiration, photosynthesis and other processes related to gaseous diffusion from and into a leaf.

Read at the Chugoku-Shikoku Chapter Meeting, Yamaguchi, 20 November, 1987

Received April 17, 1989

Current Affiliation: * Ehime Prefecture, ** Chugoku-

Shikoku Regional Agricultural Administration Office
Although many characteristics of the transfer coefficient have been revealed (Balding and Cunningham, 1976; Haseba, 1984; Haseba et al., 1987), those in light winds have been scarcely studied, except for the work by Slatyer and Bierhuizen (1964) and Vogel (1970).

A low-speed wind tunnel was constructed by Haseba et al. (1988) to produce stable laminar air flows with speeds ranging from 15 to 150 $\mathrm{cm} \cdot \mathrm{sec}^{-1}$. By means of this wind tunnel, watervapor transfer coefficients for a flat leaf model in parallel light air flows were evaluated for cases where the Reynolds number was less than $5 \times 10^{3}$. The transfer coefficients were expressed as the sum of a term proportional to the 0.5 th power of, and that inversely proportional to the 0.3 th power of the Reynolds number.

\section{Low-speed wind tunnel}

For the present experiments, a large wind tunnel 
was made on the same principle as that employed by Haseba et al. (1988), to carry out experiments on fairly large leaf models. The principal duct had a $25 \mathrm{~cm} \times 25 \mathrm{~cm}$ square cross-section and a length of $125 \mathrm{~cm}$. The vertical duct for heating the air was equipped with seven $1 \mathrm{~kW}$ electric heaters, which induced the air flow in the principal duct. Exhaust air was cooled with a laboratory airconditioning system. The contractor had a 9:1 reduction ratio and the diffuser had an angle of $22^{\circ}$.

The air flow in the duct was visualized using a dandelion pappus (Sakagami, 1975; Haseba et al., 1988). Laminar flows with little turbulence were confirmed by photographic measurements at flow speeds ranging from 10 to $130 \mathrm{~cm} \cdot \mathrm{sec}^{-1}$.

The distribution of flow speed and the intensity of turbulence were measured by means of a hotwire anemometer (Haseba et al., 1988) in several cross-sections.

At distances from $30-50 \mathrm{~cm}$ downstream from the air-inlet of the duct, flow speeds along the axis agreed with those at $40 \mathrm{~cm}$ within $\pm 1.5 \%$.

When flow speeds at the center of the section at a distrance of $40 \mathrm{~cm}$ were $8-95 \mathrm{~cm} \cdot \mathrm{sec}^{-1}$, the deviations of the speeds from the axial value at 40 $\mathrm{cm}$ were within $\pm 5 \%$. Flow speeds near the corners were more than $5 \%$ less than the axial one. The intensities of turbulence were less than 0.03 .

Accordingly, a $20 \mathrm{~cm}$ portion of the duct $30-$ $50 \mathrm{~cm}$ downstream from the inlet was selected as the test section.

Profiles of flow speed when the leaf model was excluded were compared with those of a flat square model $(16 \mathrm{~cm} \times 16 \mathrm{~cm})$ set horizontally 10 $\mathrm{cm}$ above the bottm (Fig. 1).

In the absence of the model, the flow speed and the turbulence intensity were unifrom in both sections. When the model was included, at a point equal to the height of the model and $2 \mathrm{~cm}$ upstream from the leading edge of the model (Fig. $1 \mathrm{~A})$, the flow speeds were reduced by $2 \%$ at maximum, in comparison with those obtained without the model. In contrast, at the height of the model $2 \mathrm{~cm}$ downstream from the trailing edge (Fig. 1B), the flow speeds obtained with the model were distinctly reduced. At other points, the flow speed and turbulence intensity showed fairly unifrom distributions for both setups.

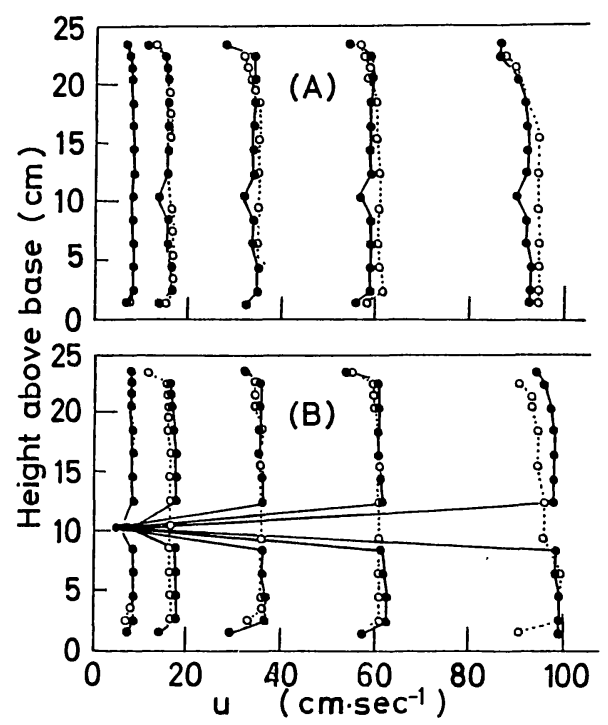

Fig. 1. Profiles of flow speed in the test section at various speeds; (A) $2 \mathrm{~cm}$ upstream from the leading edge of a horizontal model, and (B) $2 \mathrm{~cm}$ downstream from the trailing edge. Solid and clear circles indicate profiles with and without the leaf model, respectively.

\section{Water-vapor transfer coefficient}

\subsection{Methods}

The average theoretical coefficient for forced convection $\left(D_{f}, \mathrm{~cm} \cdot \mathrm{sec}^{-1}\right)$ is given by the following equation (Haseba, 1984) for water-vapor transfer across the boundary layer on a rectangular flat plate of uniform temperature in a parallel air flow.

$$
D_{f}=0.664 S c^{1 / 3} R e^{1 / 2} d / l,
$$

where $S c$ is the Schmidt number, Re, the Reynolds number defined by the length $(l, \mathrm{~cm})$ of the plate in the direction of the air flow, and $d\left(\mathrm{~cm}^{2} \cdot \mathrm{sec}^{-1}\right)$, the molecular diffusion coefficient of water vapor into air.

The average theoretical natural convective vapor transfer coefficient $\left(D_{n}, \mathrm{~cm} \cdot \mathrm{sec}^{-1}\right)$ is given by

$$
D_{n}=A(G r \cdot S c)^{1 / 4} d / L,
$$

where $G r$ is the Grashof number defined by the mean length $(L, \mathrm{~cm})$ of the sides of a rectangular plate, and $A$ is a constant. The value of $A$ is 0.54 for the upper surface of a horizontal plate with upward natural convection, or for the lower surface with a downward convection, and 0.27 for the opposite surfaces respectively to those men- 
tioned above.

Average vapor transfer coefficients obtained from the experiment $\left(D, \mathrm{~cm} \cdot \mathrm{sec}^{-1}\right)$ were arranged with reference to a theoretical analysis conducted by Mori (1961). Relationships among $\left(D / D_{f}-1\right)$ and $R e, G r$ and the aspect ratio of the model will be investigated. $\left(D / D_{f}-1\right)$ means the correction factor of a transfer-coefficient increment-ratio $\left(D / D_{f} ;\right.$ Haseba and Ito, 1980$)$.

Experiments on evaporation from leaf models were carried out in two ways.

Vapor transfer coefficients were evaluated for a fixed-size leaf model using various temperature differences between the model surface and the air. A heater made of a sheet of electrically resistant material was built into the model (Haseba and Takechi, 1973). The heating load was controlled in order to maintain the required temperature of the wet surface of the model. As the model was heated uniformly, the surface temperature varied along the direction of flow. The effect of temperature distribution on the transfer was taken into account in the evaluation of the average transfer coefficients, which will be described later.

The leaf model was a rectangular plate $5 \mathrm{~cm}$ long in the direction of flow, $10 \mathrm{~cm}$ wide transverse to the flow, and about $0.7 \mathrm{~mm}$ thick. For a plate of this size, the effect of advection around the edge of the plate on the transfer is negligible (Haseba and Ito, 1980).

The upper surface of the plate was covered with wetted blotting paper from which evaporation occurred. The model was placed parallel to a horizontal air flow in the test section of the wind tunnel. Details of the method of measurement were given in the previous paper (Haseba et al., 1988), including the average amount of evaporation (weighing method), wet surface temperature (copper-constantan thermocouple $0.1 \mathrm{~mm}$ in diameter), flow speed (hot-wire anemometer) and the dry- and wet-bulb temperatures of the air (Assmann ventilated psychrometer). Flow speed was estimated using a hot-wire anemometer calibrated by a tracer method (Taneda, 1977). The hot wire was placed at a point $10 \mathrm{~cm}$ downstream from the center of, and $5 \mathrm{~cm}$ above the model surface. The setting of the hot wire scarcely disturbed the flow near the model. The flow speed was set between 10 and $130 \mathrm{~cm} \cdot \mathrm{sec}^{-1}$.
The difference between the temperatures of the wet surface and the air was adjusted to between $-4.5^{\circ}$ and $6.7^{\circ} \mathrm{C}$. Consequently, the Grashof number changed from $1.5 \times 10^{3}$ to $2.8 \times 10^{5}$ for a downward natural convection and from $3.3 \times 10^{3}$ to $5.8 \times 10^{5}$ for an upward one. Experiments were performed at a fixed air temperature between $13^{\circ}$ and $18^{\circ} \mathrm{C}$ and at a certain relative humidity between $25 \%$ and $35 \%$.

Water-vapor density distribution on a wet surface affects the vapor transfer coefficient (Levy, 1952). In order to estimate the average transfer coefficient from the local wet surface temperature, some theoretical considerations and a specific technique are required (Haseba, 1973; Takechi and Haseba, 1973). Here, the distribution of vapor density difference between a local point of the surface and the air $\left(\Delta C_{x}, \mathrm{~g} \cdot \mathrm{cm}^{-3}\right)$ was examined as a function of the distance from the leading edge to a local point on the model $(x, \mathrm{~cm})$. Haseba (1973) showed that $\Delta C_{x}$ can be given approximately by

$$
\Delta C_{x}=a x^{n} .
$$

Values determined for the exponent $(n)$ ranged from 0.05 to 0.21 , and therefore, according to the results by Takechi and Haseba (1973), the average vapor density difference was estimated using the local temperature at a point about $2 \mathrm{~cm}$ downstream from the leading edge of the present model $5 \mathrm{~cm}$ in length. The average vapor transfer coefficient was calculated as a quotient of the average evaporation rate divided by the local vapor density difference.

On the other hand, in order to clarify the dimensional dependence of the transfer coefficient, the average evaporation rate was measured for models with various dimensions and without heating. These models had almost uniform wet surface temperatures, i.e., a uniform vapor density difference. As the model lengths and widths were $1,2,4,8$ and $16 \mathrm{~cm}$, respectively, 25 combinations of the leaf model size were used. The variation of the model dimension changed respective $G r$ for models with similar surface temperature. The experimental methods were the same as those for the heated model described above. 


\subsection{Results}

3.2.1 Water-vapor transfer coefficients for leaf models with various surface temperatures

Experimental average transfer coefficients $(D$, $\mathrm{cm} \cdot \mathrm{sec}^{-1}$ ) for the upper surface of a horizontal rectangular leaf model $5 \mathrm{~cm}$ long and $10 \mathrm{~cm}$ wide are illustrated in Fig. 2 as a function of flow speed $\left(u, \mathrm{~cm} \cdot \mathrm{sec}^{-1}\right)$.

At flow speeds higher than about $1 \mathrm{~m} \cdot \mathrm{sec}^{-1}$, the values of $D$ were nearly equal to $D_{f}$. Over a range of speeds less than about $1 \mathrm{~m} \cdot \mathrm{sec}^{-1}, D$ was larger than $D_{f}$. At very low speeds, $D$ was up to about $10 \%$ larger than $D_{f}$.

The sum of $D_{n}$ and $D_{f}$ was sometimes used as a
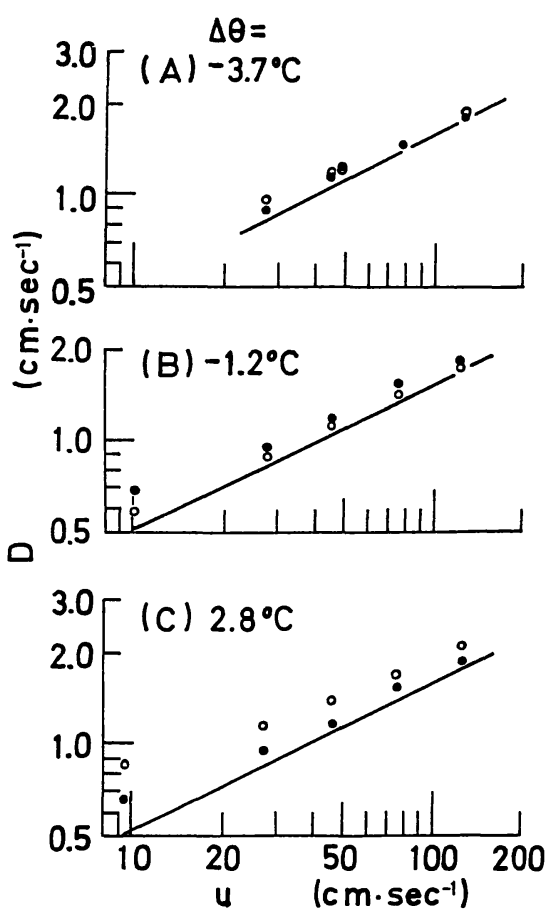

Fig. 2. Average vapor transfer coefficient ( $D$, solid circles) for a uniformly heated flat leaf model $5 \mathrm{~cm}$ long and $10 \mathrm{~cm}$ wide as a function of flow speed $(u)$; (A), (B) and (C) are the results for respective model with surface-air temperature differences $(\Delta \theta)$ of $-3.7^{\circ} \mathrm{C},-1.2^{\circ} \mathrm{C}$ and $2.8^{\circ} \mathrm{C}$ at $2 \mathrm{~cm}$ downstream from the leading edge of the model, i.e., with Grashof numbers of $1.7 \times 10^{5}$, $1.5 \times 10^{4}$ and $2.9 \times 10^{5}$, respectively.

Bold lines show the theoretical laminar forced-convection coefficient $\left(D_{f}\right)$. Clear circles indicate the sum of the free- and forced-convection coefficients. transfer coefficient under the influence of buoyancy (e.g., Haseba et al., 1980).

For an upper surface with a downward natural convection and a large Grashof number (Fig. 2A), $D$ was nearly equal to $\left(D_{n}+D_{f}\right)$. For one with a downward convection and a relatively small Grashof number (Fig. 2B), $D$ was slightly larger than $\left(D_{n}+D_{f}\right)$. On the other hand, for an upper surface with an upward natural convection and a large Grashof number (Fig. 2C), $D$ was smaller than $\left(D_{n}+D_{f}\right)$ and lies in the region from $\left(D_{n}+D_{f}\right)$ to $D_{f}$ in the figure. These facts suggest that $\left(D_{n}\right.$ $\left.+D_{f}\right)$ is not suitable as a boundary-layer transfer coefficient in light winds.

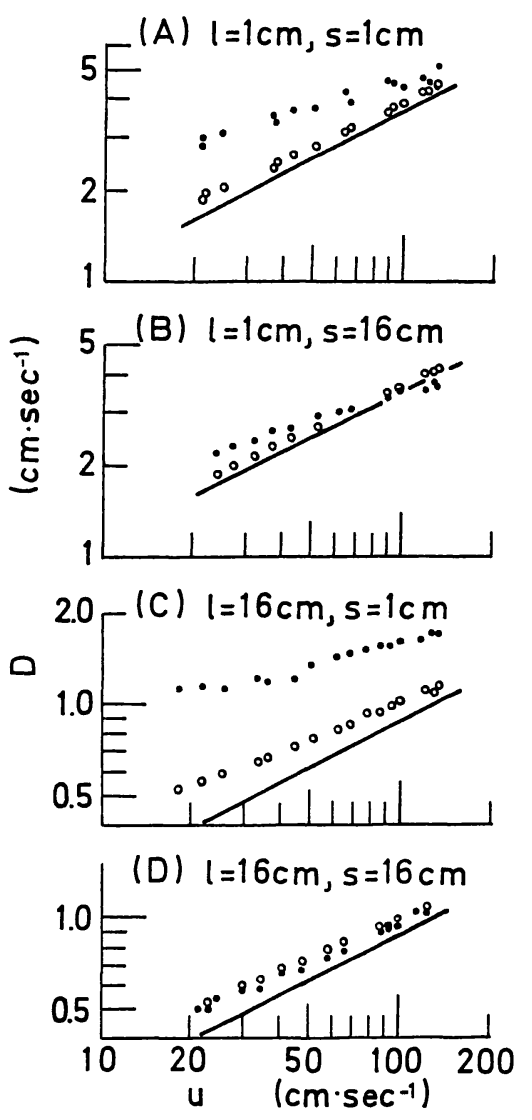

Fig. 3. The average vapor transfer coefficient $(D$, solid circles) for non-heated models of various lengths $(l)$ and widths $(s)$ vs. flow speed $(u)$; (A) for a small model, (B) for a wide one, (C) for a narrow one and (D) for a broad one.

Bold lines indicate theoretical forcedconvection transfer coefficients and clear circles indicate $\left(D_{n}+D_{f}\right)$. 


\subsubsection{Water-vapor transfer coefficients for leaf models of various dimensions and cooler than air}

Fig. 3 shows several relationships between the experimental average transfer coefficient and the flow speed for non-heated leaf models of various dimensions. The temperature difference between the surface and the air ranged from $-2.2^{\circ}$ to $-5.0^{\circ} \mathrm{C}$; accordingly, natural convection was downward.

For a small model (Fig. 3A) or a narrow one (Fig. 3C), $D$ was rather larger than $D_{f}$. $D$ for a broad model (Fig. 3D) or a wide one (Fig. 3B) showed similar values to $D_{f}$ at flow speeds higher than about $1 \mathrm{~m} \cdot \mathrm{sec}^{-1}$ and slightly larger values than $D_{f}$ in a range less than $1 \mathrm{~m} \cdot \mathrm{sec}^{-1}$.

\section{Discussion}

For a vertical flat plate, Kreith (1966) discussed the effect of natural convection on the boundarylayer transfer coefficient. On the basis of Kreith's result, Monteith (1973) presented a rough criterion for distinguishing the forced and natural convections by comparisons between $G r$ and $R e^{2}$.

On the other hand, Mori (1961) investigated theoretically the heat transfer across the boundarylayer on the upper surface of a horizontal semiinfinite flat plate at low flow speeds. An equation expressing the effect of buoyancy on the transfer coefficient was derived as a function of the Grashof and Reynolds numbers.

Because, in the present experiments, horizontal flat plates were used as leaf models, the experimental data were arranged according to Mori's expression.

Examples of the relationships between $\left(D / D_{f}\right.$ $-1)$ and $R e$ are shown in Fig. 4 for the coefficients obtained from the uniformly heated models with nearly equal Grashof numbers.

Linear relationships are recognized between $\log \left(D / D_{f}-1\right)$ and $\log R e$. An increase in $\left(D / D_{f}\right.$ -1 ) over small range of Reynolds number suggests that the increase in the effect of bouyancy on the transfer coefficient is dominant in light winds.

In a similar range of Reynolds number values, several examples of relationships between $\left(D / D_{f}\right.$ $-1)$ and $G r$ are presented in Fig. 5.

Although the regression lines in Fig. 5 show only a slight relationship between $\left(D / D_{f}-1\right)$ and $G r$,

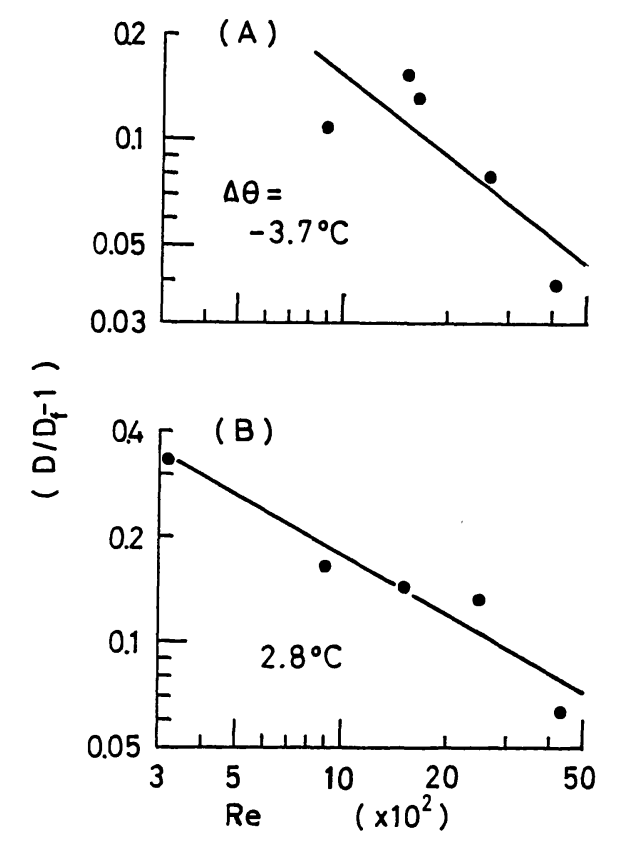

Fig. 4. $\left(D / D_{f}-1\right)$ vs. Reynolds number $(R e)$, with approximately same Grashof numbers; (A) and (B) are for models of $1.9 \times 10^{5}$ and $2.9 \times 10^{5}$ in $\mathrm{Gr}\left(-3.7^{\circ} \mathrm{C}\right.$ and $2.8^{\circ} \mathrm{C}$ in surface-air temperature difference, $\Delta \theta$ ), respectively.

$D$ is an experimental transfer coefficient affected by buoyancy and $D_{f}$ is the theoretical forced convection one.

\section{(A) $\operatorname{Re}=3.4 \times 10^{2}\left(u=10 \mathrm{~cm} \cdot \mathrm{sec}^{-1}\right)$}

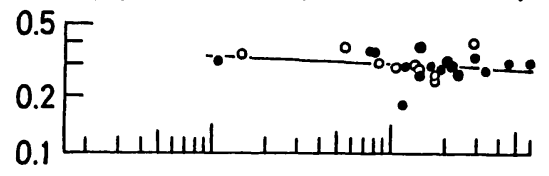

(B) $\operatorname{Re} \approx 9.2 \times 10^{2}\left(u=26 \mathrm{~cm} \cdot \mathrm{sec}^{-1}\right)$

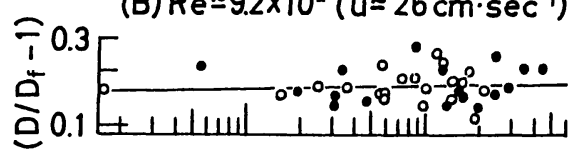

(C) $\operatorname{Re}=2.6 \times 10^{3}\left(u=78 \mathrm{~cm} \cdot \mathrm{sec}^{-1}\right)$

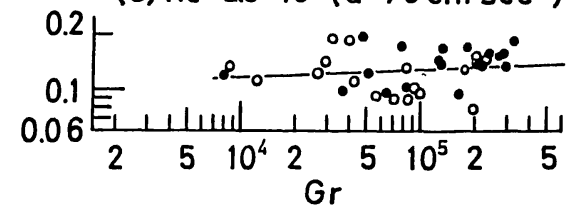

Fig. 5. $\left(D / D_{f}-1\right)$ vs. Grashof number $(G r)$, with nearly equal Reynolds numbers.

Solid and clear circles indicate $\left(D / D_{f}-1\right)$ for models with upward and downward natural convections, respectively. 
this relationship cannot be neglected because of the wide range and large values of $G r$. The values of $\left(D / D_{f}-1\right)$ for both models with upward and downward natural convections are nearly equal.

An experimental equation was formulated as follows (Mori, 1961; Haseba et al., 1988).

$$
D / D_{f}-1=B G r^{n} R e^{-m} .
$$

By the method of least squares, the following equation was obtained,

$$
D / D_{f}-1=10 G r^{0.02} R^{-0.62},
$$

where the coefficient of determination was 0.64 .

The dimensional dependence of the transfer coefficient was not included in Eq. (5) which was obtained from experiments using a broad leaf model (Haseba and Ito, 1980). Accordingly, the obtained exponents $n$ and $m$ of $G r$ and $R e$ in Eq. (5) can be used for the arrangement of $\left(D / D_{f}-1\right)$ obtained from the experiments on models of various dimensions.

The dimensional dependence of the transfer coefficients is shown in Fig. 6 as a function of the aspect ratio $(l / s)$.

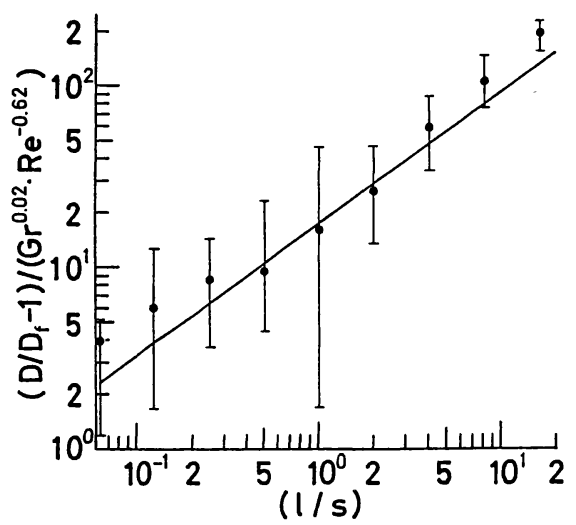

Fig. 6. Aspect ratio $(l / s)$ dependence of the proportionality coefficient $B$ in Eq. (4) in the case when $n=0.02$ and $m=-0.62$ for a flat leaf model in light winds.

Vertical lines indicate the range of experimental data spread and solid circles are the mean values.

An experimental equation was formulated as

$$
D / D_{f}-1=B^{\prime}(l / s)^{p} G r^{0.02} R e^{-0.62} .
$$

Using all experimental transfer coefficients for models with both positive and negative surface-air temperature differences, the following was obtained by the method of least squares in the coefficient of determination of 0.79 ,

$$
D / D_{f}-1=18(l / s)^{0.73} \mathrm{Gr}^{0.02} \operatorname{Re}^{-0.62} .
$$

This is applicable over the renge

$$
\begin{aligned}
& 3.6 \times 10^{2}<G r<1.6 \times 10^{6} \text { and } \\
& 1.5 \times 10^{2}<\operatorname{Re}<1.3 \times 10^{4} .
\end{aligned}
$$

The vapor transfer coefficient in light winds at a reference temperature of $20^{\circ} \mathrm{C}$ can be rewritten in the following form according to Eq. (7),

$$
D=D_{f}+2.0 l^{-0.39} s^{-0.73} \mathrm{Gr}^{0.02} u^{-0.12} \text {. }
$$

Under conditions of light wind, an air temperature of $20^{\circ} \mathrm{C}$, a relative humidity of $60 \%$ and a leaf-air temperature difference of $0^{\circ} \mathrm{C}$, for example, the increment ratios of the transfer coefficient $\left(D / D_{f}\right)$ are represented in Fig. 7 for models of various dimensions as a function of wind speed (u).

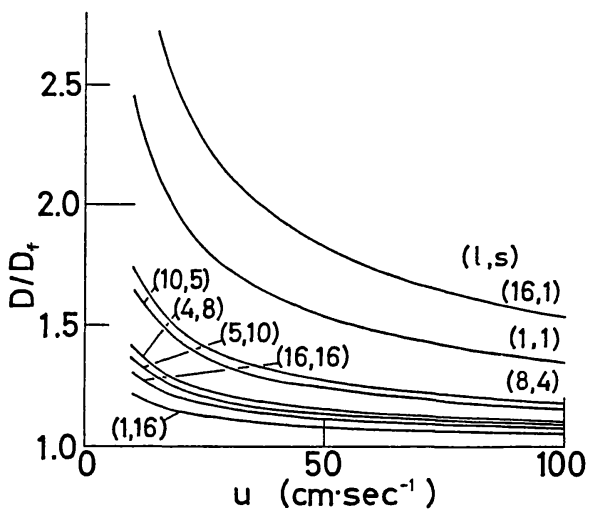

Fig. 7. Calculated increment ratio of the transfer coefficient $\left(D / D_{f}\right)$ in light winds as a function of wind speed $(u)$ for leaves of various lengths $(l, \mathrm{~cm})$ and widths $(s, \mathrm{~cm})$ at the same temperature of $20^{\circ} \mathrm{C}$ for both air and leaf, and a relative humidity of $60 \%$.

The ratio is large for a long or narrow leaf at low wind speeds. At a wind speed of $10 \mathrm{~cm} \cdot \mathrm{sec}^{-1}$, the transfer coefficient for a leaf $10 \mathrm{~cm}$ long and $5 \mathrm{~cm}$ wide is estimated to be $0.65 \mathrm{~cm} \cdot \mathrm{sec}^{-1}$ from Eq. (8). This value is smaller than the stomatal conductance for a leaf with well opened stomata (Slatyer and Bierhuizen, 1964; Monteith et al., 1965); therefore, in this situation the leaf boundary-layer transfer coefficient is probably 
one of the limiting factors of gas transfer for a plant leaf.

On the other hand, the experimental equation for the vapor transfer coefficient of a $5 \mathrm{~cm} \times 10$ $\mathrm{cm}$ rectangular leaf model obtained by Haseba $e t$ al. $(1988)$ is

$$
D / D_{f}-1=33 R e^{-0.81},
$$

which is applicable over a range of Grashof numbers from $2 \times 10^{5}$ to $3 \times 10^{5}$. When using the present exponents of 0.02 for $G r$ and -0.62 for $R e$, Eq. (9) is rearranged as follows,

$$
D / D_{f}-1=6.9 G r^{0.02} R e^{-0.62} \text {. }
$$

This equation is similar to Eq. (5) obtained here.

Haseba and Ito (1980) showed that at wind speeds of more than about $1 \mathrm{~m} \cdot \mathrm{sec}^{-1}$, an increase in the boundary-layer transfer coefficient is dependent on the dimensions of the leaf and independent of wind speed. However, at lower wind speeds, an increase in the coefficient, as shown in Eq. (8), is dependent on the leaf-air temperature difference, the water vapor density difference between the leaf surface and the air, the wind speed and the leaf dimensions. This means that, in light winds, the increase in the transfer coefficient results from buoyancy i.e., free convection as discussed theoretically by Mori (1961), and advection around the edge.

The theoretical value of $\left(N u_{x} / N u_{f}-1\right)$ obtained for a local Nusselt number $\left(N u_{x}\right)$ by Mori (1961) is 0.04 in the case of a $G r_{x}$ of $1 \times 10^{5}$ and a $R e_{x}$ of $1 \times 10^{3}$. Unfortunately, the value of 0.04 is very far from an average coefficient of 0.19 obtained using Eq. (5). Theoretical analyses of the transfer phenomena for a finite plate in light winds are therefore desirable.

Furthermore, the leaf boundary-layer transfer coefficient in the field should be measured and compared with the results obtained here.

\section{Reference}

Balding, F. R. and Cunningham, G. L., 1976: A comparison on heat transfer characteristics of simple and pinnate leaf models. Bot. Gaz., 134, 65-74.

Haseba, T., 1973: Agro-meteorological studies of transpiration in plant leaf in relation to the environment. Mem. Coll., Ehime Univ., 18, 1-
141.*

Haseba, T., 1984: Convection coefficient of transfer across the boundary layer on plant leaf surface. J. Agr. Met., 40, 63-72.*

Haseba, T.; Aibara, K.; Matsuoka, H. and Ito, D., 1988: A test of low-speed wind tunnel for evalution of leaf boundary-layer transfer coefficient. J. Agr. Met., 44, 175-180.*

Haseba, T. and Ito, D., 1980: Dimension dependence of boundary-layer transfer coefficient of water-vapor for flat plant leaf. J. Agr. Met., 36, 89-94.

Haseba, T., Ito, D. and Nishikawa, A., 1987: Boundary-layer transfer coefficient for a fluttering leaf II. Model experiments to evaluate effects of leaf inclination and fluttering on transfer coefficient. J. Agr. Met., 43, 105-111.

Haseba, T. and Takechi, O., 1972: Studies of transpiration in relation to the environment (4) Influence of wind speed on transpiration. J. Agr. Met., 28, 93-101.*

Haseba, T. and Takechi, O., 1973: Local watervapor transfer coefficient on horizontal leafshaped plane surface under field conditions. $J$. Agr. Met., 28, 149-155.*

Haseba, T., Takeuchi, Y. and Toyama, M., 1980: Estimation of transpiration amount and energy balance of sugar beets in the field under arid conditions. Bull. Sand Dune Res. Inst., Tottori Univ., 19, 91-99.

Impens, I. I., Stewart, D. W., Allen, L. H., Jr. and Lemon, E. R., 1967: Diffusive resistances at, and transpiration rates from leaves in situ within the vegetative canopy of a corn crop. Plant Physiol., 42, 99-104.

Kreith, F., 1965: Principles of Heat Transfer. International Textbook Co., Scranton, 357358.

Levy, S., 1952: Heat transfer to constant-property laminar boundary-layer flows with powerfunction free-stream velocity and wall-temperature variation. J. Aeron. Sci., 19, 341-348.

Monteith, J. L., 1973: Principles of Environmental Physics. Edward Arnold, London, 103-104.

Monteith, J. L., Szeicz, G. and Waggoner, P. E., 1965: The measurements and control of stomatal resistance in the field. J. Appl. Ecol., 2, 345-355.

Mori, Y., 1961: Buoyancy effects in forced laminar convection flow over a horizontal flat plate. J. Heat Transfer, 83, 479-482.

Sakagami, J., 1975: Flow visualization II Air flow visualization. Kisho-Kenkyu Note, 124, 4-5.**

Slatyer, R. O. and Bierhuizen, J. F., 1964: Transpiration from cotton leaves under a range of environmental conditions in relation to internal 
and external diffusive resistances. Aust. J. Biol. Sci., 17, 115-130.

Takechi, O. and Haseba, T., 1973: Water-vapor transfer by forced-convection from a leaf-shaped plane surface with temperature-distribution. $J$. Agr. Met., 28, 213-221.*

Taneda, S., 1977: Tracer method. In Handbook of Fluid Flow Visualization (ed. by T. Asa- numa). Asakura, Tokyo, 169-231.

Vogel, S., 1970: Convective cooling at low airspeeds and the shapes of broad leaves. J. Exptl. Bot., 21, 91-101.

*, written in Japanese with English summary, $* *$, written in Japanese.

\section{微風域において浮力の影響を受ける 葉面境界層輸送係数 \\ 長谷場徹也・相原研二・守屋公二・西川 敦・伊藤代次郎 \\ (愛媛大学農学部) \\ 要 \\ 約}

テストセクションの断面が $25 \times 25 \mathrm{~cm}^{2}$ の正方形で, 長さが $20 \mathrm{~cm}$ である熱対流方式の微速風洞を試作し, 流 速が 10 から $130 \mathrm{~cm} \cdot \mathrm{sec}^{-1}$ の範囲で, 乱れの強さが 0.02 以下の層流気流を作ることができた。

乙の風洞を用いて, 微風域における模型葉面の水蒸気 輸送係数の特性を調べた。実験は，一定寸法の面の蒸発 面温度と気温との差を変えた場合，ならびに蒸発面温度 と気温との差を一定にして，面の寸法を変えた場合につ いて行った。
輸送係数の実測值は層流強制対流理論值より大きかっ た。微風域における水蒸気輸送係数を, Aspect Ratio (面の気流方向の長さ之幅との比), Grashof 数及び Reynolds 数との関数として求めた。

これより, 微風域において, 模型葉の境界層輸送係数 が強制対流輸送係数より大きくなる原因は, 面上の自由 対流ならびに面の周縁に打ける移流による輸送の増大で あるととが明らかにされた。 